\title{
First human case of catheter-related blood stream infection caused by Staphylococcus schleiferi subspecies coagulans: a case report and literature review
}

Tatsuya Kobayashi ${ }^{1}$, Mahoko Ikeda 1,3*0, Yuki Ohama ${ }^{3}$, Koji Murono ${ }^{2}$, Kazuhiko Ikeuchi ${ }^{1}$, Satoshi Kitaura', Koh Okamoto', Shu Okugawa', Soichiro Ishihara² and Kyoji Moriya ${ }^{1,3}$

\begin{abstract}
Background: Staphylococcus schleiferi is a gram-positive pathogenic coccus which causes canine skin and ear infections. Only four cases of human infection caused by Staphylococcus schleiferi subspecies coagulans have been reported. Herein, we present the first case of catheter-related bloodstream infection caused by S. schleiferi subspecies coagulans.

Case presentation: A 62-year-old Japanese man was admitted to our hospital for examination of sigmoid colon tumor. During hospitalization, he had fever, shaking chills, and swelling at the peripheral venous catheter insertion site. Two sets of blood cultures were positive for $S$. schleiferi subspecies coagulans which was confirmed using matrixassisted laser desorption/ionization time-of-flight mass spectrometry (MALDI-TOF MS), 165 ribosomal RNA sequencing and the coagulase test. The patient was successfully treated without relapse.

Conclusion: To our knowledge, this is the first report of catheter-related bloodstream infection caused by S. schleiferi subspecies coagulans. S. schleiferi subsp. coagulans can be pathogenic in humans, and MALDI-TOF MS can contribute to accurate identification of $S$. schleiferi subspecies coagulans.
\end{abstract}

Keywords: Staphylococcus schleiferi subspecies coagulans, Catheter-related bloodstream infection, Matrix-assisted laser desorption/ionization time-of-flight mass spectrometry, 16S ribosomal RNA sequencing

\section{Background}

Staphylococcus schleiferi is associated with otitis externa and pyoderma in dogs [1]. It has two subspecies, $S$. schleiferi subsp. schleiferi and S. schleiferi subsp. coagulans that are coagulase-negative and coagulase-positive, respectively. There are multiple case reports of $S$. schleiferi infection including skin and soft tissue infections, wound and surgical site infections [2], device infections [3], urinary tract infection [4], and endocarditis [5]. A review of 28 case series of $S$. schleiferi infection has been reported in 2001 [6], and all isolates were coagulase-negative.

However, only four cases of human infection caused by S. schleiferi subsp. coagulans have been reported. Here, we report the first case of catheter-related bloodstream infection caused by S. schleiferi subsp. coagulans.

\footnotetext{
*Correspondence: mhk-ikeda@umin.ac.jp

${ }^{3}$ Department of Infection Control and Prevention, University of Tokyo

Hospital, 7-3-1, Hongo, Bunkyo-ku, Tokyo 113-8655, Japan

Full list of author information is available at the end of the article
}

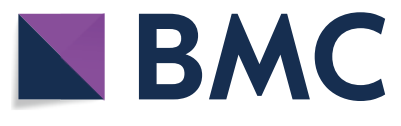

(c) The Author(s) 2021. Open Access This article is licensed under a Creative Commons Attribution 4.0 International License, which permits use, sharing, adaptation, distribution and reproduction in any medium or format, as long as you give appropriate credit to the original author(s) and the source, provide a link to the Creative Commons licence, and indicate if changes were made. The images or other third party material in this article are included in the article's Creative Commons licence, unless indicated otherwise in a credit line to the material. If material is not included in the article's Creative Commons licence and your intended use is not permitted by statutory regulation or exceeds the permitted use, you will need to obtain permission directly from the copyright holder. To view a copy of this licence, visit http://creativecommons.org/licenses/by/4.0/. The Creative Commons Public Domain Dedication waiver (http://creativeco mmons.org/publicdomain/zero/1.0/) applies to the data made available in this article, unless otherwise stated in a credit line to the data. 


\section{Case presentation}

A 62-year-old Japanese man presented to a local gastroenterology clinic with narrow stools. He had hypertension and prostatic hypertrophy. His only regular medication was amlodipine. Colonoscopy revealed a subcircumferential tumor in the sigmoid colon, and the colonoscope did not pass through the tumor. He was referred to our hospital for further examination of a sigmoid colon tumor. Bowel obstruction due to sigmoid colon cancer was suspected, and he was admitted to our hospital. Fasting and fluid administration were performed until surgical resection of the tumor.

Seven days after admission, he had a fever of $38.1^{\circ} \mathrm{C}$ with shaking chills but was alert and oriented and not in acute distress. Additionally, his vital signs were as follows: pulse rate 72 beats/min, blood pressure $118 / 60 \mathrm{mmHg}$, respiratory rate 16 breaths/min, and oxygen saturation 98\% while breathing ambient air. Physical examination revealed redness, swelling, and tenderness at the short peripheral venous catheter insertion site in his right forearm. He did not have a heart murmur, neurological abnormalities, or other abnormalities on physical examination. He denied a history of trauma, intravenous drug use, and contact with animals including dogs.

Laboratory tests showed the following results: white blood cell count 9000/ $\mu$ l (neutrophil 79.9\%) and C-reactive protein $5.72 \mathrm{mg} / \mathrm{dl}$. His serum creatinine and liver function tests were normal. A computed tomography scan showed no abnormal findings except for the previously known sigmoid colon tumor.

Because catheter-related bloodstream infection was suspected, a peripheral venous catheter was replaced. Piperacillin/tazobactam ( $4.5 \mathrm{~g}$ every $8 \mathrm{~h}$ ) was initiated after two sets of blood cultures were collected. The blood cultures were collected from separate venipuncture sites by using aseptic non-touch technique. On the following day, both sets of blood cultures were positive for clusters of gram-positive cocci. Therefore, vancomycin ( $1 \mathrm{~g}$ every $12 \mathrm{~h}$ ) was initiated additionally.

The isolate was identified using matrix-assisted laser desorption/ionization time-of-flight mass spectrometry (MALDI-TOF MS), using a MALDI Biotyper (Bruker Daltonics, Bremen, Germany, Version 4.0) as S. schleiferi subsp. coagulans (log score 1.945).

The results were confirmed using $16 \mathrm{~S}$ ribosomal RNA sequencing. Comparison with sequences in the BLAST database (http://www.ncbi.nlm.nih.gov/BLAST) revealed that the sequence was $100 \%$ identical to that of S. schleiferi (GenBank accession number AP014944.1). The isolate was free coagulase-positive and thus, was identified as $S$. schleiferi subsp. coagulans. Coagulase activity was tested by using rabbit plasma (Eiken Chemical Co., Ltd., Tokyo, Japan).
Antimicrobial susceptibility testing was performed using the MicroScan WalkAway system (Beckman Coulter, Tokyo, Japan). The isolate was susceptible to all antibiotics tested including oxacillin, cefazolin, clindamycin, and vancomycin according to the Clinical and Laboratory Standards Institute M100-S29 [7]. The minimum inhibitory concentration for oxacillin was $\leq 0.25 \mu \mathrm{g} / \mathrm{ml}$.

The isolate did not produce Staphylococcal enterotoxin (SE, SEA to SED) or toxic shock syndrome toxin-1 (TSST-1) as per reversed passive latex agglutination assay (Denka Co., Ltd., Tokyo, Japan).

The patient's antibiotic treatment was switched to cefazolin ( 1 g every $8 \mathrm{~h}$ ) on day 5 based on the results of the antimicrobial susceptibility testing. His fever and chills improved following antibiotic treatment. Repeated blood cultures after antibiotic treatment were negative. He was treated for eight days with intravenous antibiotic therapy. The patient successfully underwent laparoscopic sigmoid colectomy without relapse of S. schleiferi bacteremia.

\section{Discussion and conclusion}

S. schleiferi was first reported as a new species in 1988 [8], and S. schleiferi subsp. coagulans can be differentiated from $S$ schleiferi subsp. schleiferi based on coagulase production [9]. S. schleiferi is frequently isolated from the skin and external ear of dogs [10] and is recognized as one of the pathogens causing canine otitis externa [9].

While various human cases of $S$. schleiferi infection have been described previously, human infection caused by S. schleiferi subsp. coagulans is rare. Only four cases of $S$. schleiferi subsp. coagulans infection have been reported previously including two cases of endocarditis $[5,11]$, a case with left ventricular assist device infection [12], and a case with bacteremia (entry site undescribed) [13] (Table 1). None of the patients died of S. schleiferi subsp. coagulans infection.

Both sets of blood cultures taken from the patient were positive for S. schleiferi subsp. coagulans and there was redness, swelling, and tenderness at the peripheral venous catheter insertion site. These clinical symptoms were resolved after withdrawal of the peripheral venous catheter. There was no other alternative explanation for bacteremia, and S. schleiferi subsp. coagulans can colonize on skin of human, especially who has contact with dogs [14]. For these reasons, we diagnosed his condition as catheter-related bloodstream infection. However, the patient denied contact with the dogs before admission. In addition, the onset of infection was a week after admission. Therefore, it is unclear how $S$. schleiferi subsp. coagulans colonized the patient's skin in this case.

There are multiple reports that coagulase-negative staphylococci can produce SE alone or in combination with TSST-1 [15-17]. However, the S. schleiferi subsp. 
Table 1 Characteristics of cases of human infection caused by Staphylococcus schleiferi subspecies coagulans

\begin{tabular}{|c|c|c|c|c|c|}
\hline Infection focus & Age/sex & Definitive antibiotic treatment & $\begin{array}{l}\text { Methicillin } \\
\text { susceptibility }\end{array}$ & Outcome & References \\
\hline Endocarditis & $78 / \mathrm{M}$ & $\begin{array}{l}\text { Benzylpenicillin, rifampin, gen- } \\
\text { tamicin }\end{array}$ & Susceptible & Survived & Leung et al. [5] \\
\hline Endocarditis & $58 / \mathrm{M}$ & Vancomycin, rifampin, gentamicin & Resistant & $\begin{array}{l}\text { Successfully treated } \\
\text { (died of liver failure) }\end{array}$ & Kumar et al. [12] \\
\hline Left ventricular assist device infection & $55 / F$ & Dicloxacillin, cephalexin & Susceptible & Survived & Thibodeau et al. [13] \\
\hline Bacteremia (entry site undescribed) & $66 / M$ & Vancomycin & Resistant & Survived & Swe et al. [14] \\
\hline Catheter related bloodstream infection & $62 / M$ & Cefazolin, clindamycin & Susceptible & Survived & This report \\
\hline
\end{tabular}

$M$ male, $F$ female

coagulans strain did not produce SEA to SED or TSST-1 in our case. Although the possession of SE genes was reported in $86 \%$ (18/21 strains) of coagulase-positive $S$. schleiferi detected from dogs, the production of SEA to SED and TSST-1 has not yet been reported [18]. As $S$. schleiferi subsp. coagulans infection is rare in humans and there are a limited number of case reports, further studies are needed to clarify the frequency of SE/TSST-1 production in S. schleiferi subsp. coagulans infection.

Various laboratory tests were performed to identify S. schleiferi subsp. coagulans in previous reports. Two reports used Vitek system (bioMérieux Vitek Inc., Hazelwood, Missouri) [5, 12]. One report used 16S ribosomal DNA sequencing, nested PCR, and the MicroScan WalkAway system (Dade-Behring, West Sacramento, California) $[5,11,12]$. Our case is the first to use MALDI-TOF MS, 16S ribosomal RNA gene sequencing for identification of S. schleiferi subsp. coagulans. S. schleiferi subsp. coagulans could have been mistaken for Staphylococcus aureus because both are free coagulase positive $[5,19]$. Accurate identification of $S$. schleiferi subsp. coagulans can be expected by combining MALDI-TOF MS and biochemical properties test.

Non-aureus Staphylococci, especially coagulase-negative Staphylococci are often resistant to methicillin [20], however, two previous cases and the present case were susceptible to methicillin $[5,11-13]$.

In summary, we present the first case of catheterrelated bloodstream infection caused by $S$. schleiferi subsp. coagulans. The organism was identified using MALDI-TOF MS, 16S ribosomal RNA gene-sequencing analysis, and free coagulase test. Therefore, although human infection is rare, S. schleiferi subsp. coagulans can be pathogenic in humans.

\section{Abbreviations}

S. schleiferi: Staphylococcus schleiferi; S. schleiferi subsp. schleiferi: Staphylococcus schleiferi subspecies schleiferi; S. schleiferi subsp. coagulans: Staphylococcus schleiferi subspecies coagulans; MALDI-TOF MS: Matrix-assisted laser desorption/ionization time-of-flight mass spectrometry; SE: Staphylococcal enterotoxin; TSST-1: Toxic shock syndrome toxin-1.

\section{Acknowledgements \\ Not applicable.}

\section{Authors' contributions}

Conceptualization: TK, Ml; microbiological investigation; TK, YO writing original draft: TK; reviewing and editing the manuscript: all authors. All authors read and approved the final manuscript.

Funding

No funding was specifically received for this study.

\section{Availability of data and materials}

All data analyzed in this study are included in this published article.

Related information is accessible under request to the corresponding author.

\section{Declarations}

Ethics approval and consent to participate

Not applicable.

\section{Consent for publication}

Written informed consent was obtained from the patient for publication of the clinical details.

\section{Competing interests}

The authors declare that they have no competing interests.

\section{Author details}

${ }^{1}$ Department of Infectious Diseases, University of Tokyo Hospital, Tokyo, Japan. ${ }^{2}$ Department of Surgical Oncology, The University of Tokyo Graduate School of Medicine, Tokyo, Japan. ${ }^{3}$ Department of Infection Control and Prevention, University of Tokyo Hospital, 7-3-1, Hongo, Bunkyo-ku, Tokyo 113-8655, Japan.

Received: 30 July 2021 Accepted: 21 September 2021

Published online: 25 September 2021

\section{References}

1. Cain CL, Morris DO, Rankin SC. Clinical characterization of Staphylococcus schleiferi infections and identification of risk factors for acquisition of oxacillin-resistant strains in dogs: 225 cases (2003-2009). J Am Vet Med Assoc. 2011;239(12):1566-73. https://doi.org/10.2460/javma.239.12.1566.

2. Kluytmans J, Berg H, Steegh P, Vandenesch F, Etienne J, van Belkum A. Outbreak of Staphylococcus schleiferi wound infections: strain characterization by randomly amplified polymorphic DNA analysis, PCR ribotyping, conventional ribotyping, and pulsed-field gel electrophoresis. J Clin Microbiol. 1998;36(8):2214-9. https://doi.org/10.1128/jcm.36.8.2214-2219. 1998. 
3. Célard M, Vandenesch F, Darbas H, Grando J, Jean-Pierre H, Kirkorian $G$, et al. Pacemaker infection caused by Staphylococcus schleiferi, a member of the human preaxillary flora: four case reports. Clin Infect Dis. 1997;24(5):1014-5. https://doi.org/10.1093/clinids/24.5.1014.

4. Oztürkeri H, Kocabeyoğlu O, Yergök YZ, Koşan E, Yenen OS, Keskin K. Distribution of coagulase-negative staphylococci, including the newly described species Staphylococcus schleiferi, in nosocomial and community acquired urinary tract infections. Eur J Clin Microbiol Infect Dis. 1994;13(12):1076-9. https://doi.org/10.1007/bf02111833.

5. Leung MJ, Nuttall N, Mazur M, Taddei TL, McComish M, Pearman JW. Case of Staphylococcus schleiferi endocarditis and a simple scheme to identify clumping factor-positive staphylococci. J Clin Microbiol. 1999;37(10):3353-6. https://doi.org/10.1128/jcm.37.10.3353-3356.1999.

6. Hernández JL, Calvo J, Sota R, Agüero J, García-Palomo JD, Fariñas MC. Clinical and microbiological characteristics of 28 patients with Staphylococcus schleiferi infection. Eur J Clin Microbiol Infect Dis. 2001;20(3):153-8. https://doi.org/10.1007/pl00011251.

7. CLSI. Performance standards for antimicrobial susceptibility testing. CLSI supplement M100. 28th ed. Wayne: Clinical and Laboratory Standards Institute; 2018.

8. Freney J, Brun Y, Bes M, Meugnier H, Grimont F, Grimont PA, et al. Staphylococcus lugdunensis sp. nov. and Staphylococcus schleiferi sp. Nov., two species from human clinical specimens. Int J Syst Evol Microbiol. 1988;38(2):168-72.

9. Igimi S, Takahashi E, Mitsuoka T. Staphylococcus schleiferi subsp. coagulans subsp. nov., isolated from the external auditory meatus of dogs with external ear otitis. Int I Syst Bacteriol. 1990;40(4):409-11. https://doi.org/ 10.1099/00207713-40-4-409.

10. Jones RD, Kania SA, Rohrbach BW, Frank LA, Bemis DA. Prevalence of oxacillin- and multidrug-resistant staphylococci in clinical samples from dogs: 1772 samples (2001-2005). J Am Vet Med Assoc. 2007;230(2):221-7. https://doi.org/10.2460/javma.230.2.221.

11. Kumar D, Cawley JJ, Irizarry-Alvarado JM, Alvarez A, Alvarez S. Case of Staphylococcus schleiferi subspecies coagulans endocarditis and metastatic infection in an immune compromised host. Transp Infect Dis. 2007;9(4):336-8. https://doi.org/10.1111/j.1399-3062.2007.00222.x.

12. Thibodeau E, Boucher $H$, Denofrio D, Pham DT, Snydman D. First report of a left ventricular assist device infection caused by Staphylococcus schleiferi subspecies coagulans: a coagulase-positive organism. Diagn Microbiol
Infect Dis. 2012;74(1):68-9. https://doi.org/10.1016/j.diagmicrobio.2012. 05.027.

13. Swe T, Naing AT, Baqui A, Khillan R. Methicillin-resistant Staphylococcus schleiferi subspecies coagulans infection in a patient with hepatocellular carcinoma. J Investig Med High Impact Case Rep. 2016;4(3):2324709616671148. https://doi.org/10.1177/2324709616 671148.

14. Chanchaithong P, Perreten V, Schwendener S, Tribuddharat C, Chongthaleong A, Niyomtham W, et al. Strain typing and antimicrobial susceptibility of methicillin-resistant coagulase-positive staphylococcal species in dogs and people associated with dogs in Thailand. J Appl Microbiol. 2014;117(2):572-86. https://doi.org/10.1111/jam.12545.

15. Crass BA, Bergdoll MS. Involvement of coagulase-negative staphylococci in toxic shock syndrome. J Clin Microbiol. 1986;23(1):43-5. https://doi. org/10.1128/jcm.23.1.43-45.1986.

16. Kahler RC, Boyce JM, Bergdoll MS, Lockwood WR, Taylor MR. Toxic shock syndrome associated with TSST-1 producing coagulase-negative staphylococci. Am J Med Sci. 1986;292(5):310-2. https://doi.org/10.1097/00000 441-198611000-00011.

17. Valle J, Vadillo S, Piriz S, Gomez-Lucia E. Toxic shock syndrome toxin 1 (TSST-1) production by staphylococci isolated from goats and presence of specific antibodies to TSST-1 in serum and milk. Appl Environ Microbiol. 1991;57(3):889-91. https://doi.org/10.1128/aem.57.3.889-891.1991.

18. Lee GY, Lee HH, Hwang SY, Hong J, Lyoo KS, Yang SJ. Carriage of Staphylococcus schleiferi from canine otitis externa: antimicrobial resistance profiles and virulence factors associated with skin infection. J Vet Sci. 2019;20(2): e6. https://doi.org/10.4142/jvs.2019.20.e6.

19. Vandenesch F, Lebeau C, Bes M, Lina G, Lina B, Greenland T, et al. Clotting activity in Staphylococcus schleiferi subspecies from human patients. J Clin Microbiol. 1994;32(2):388-92. https://doi.org/10.1128/jcm.32.2.388-392. 1994.

20. Becker K, Heilmann C, Peters G. Coagulase-negative staphylococci. Clin Microbiol Rev. 2014;27(4):870-926. https://doi.org/10.1128/cmr.00109-13.

\section{Publisher's Note}

Springer Nature remains neutral with regard to jurisdictional claims in published maps and institutional affiliations.
Ready to submit your research? Choose BMC and benefit from:

- fast, convenient online submission

- thorough peer review by experienced researchers in your field

- rapid publication on acceptance

- support for research data, including large and complex data types

- gold Open Access which fosters wider collaboration and increased citations

- maximum visibility for your research: over $100 \mathrm{M}$ website views per year

At BMC, research is always in progress.

Learn more biomedcentral.com/submissions 